\title{
Sources of carbon fuelling production in an arid floodplain river
}

\author{
Michele A. Burford ${ }^{A B}$, Andrew J. Cook ${ }^{A}$, Christine S. Fellows ${ }^{A}$, \\ Stephen R. Balcombe ${ }^{\mathrm{A}}$, Stuart E. Bunn ${ }^{\mathrm{A}}$

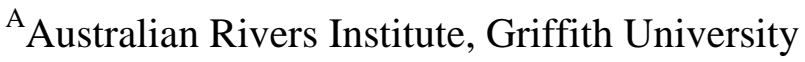 \\ Nathan, Queensland, 4111, Australia
}

${ }^{\mathrm{B}}$ Corresponding author

Email: m.burford@griffith.edu.au) 


\section{Abstract}

Dryland rivers are characterised by highly pulsed and unpredictable flow, and support a diverse biota. However, these biota are under pressure from water diversion and regulation to supply human needs, and are vulnerable to climate change impacts on the flow regime. This study examined the contribution of floodplain sources to the productivity of a disconnected dryland river, i.e. a waterhole, after a major overland flood event. Rate measures of productivity were combined with stable isotope and biomass data on the food web in the waterhole and floodplain. Our study estimated that $50 \%$ of the fish carbon in the waterhole post-flooding was derived from floodplain food sources. Based on stable isotope data, this study suggests that fish were feeding on the same aquatic carbon source on the floodplain as in the waterhole. In the few months after retraction of the river to isolated waterholes, the large biomass of fish concentrated from the flooding decreased by $80 \%$, most likely due to starvation. Based on the development of a carbon budget for the waterhole, mass mortality is hypothesized to be the cause of the high rates of heterotrophic production in the waterhole. Export of fish, via bird predation cannot be discounted, but large numbers of piscivorous birds were not observed during the study. This study suggests that floodplain inputs are important for fuelling short-term production in the waterholes, but via an unconventional pathway, i.e. fish mortality. In dryland river systems, flooding is infrequent and within-waterhole carbon sources also sustain production during dry periods. The episodic nature of flooding in dryland rivers means that changes in flow regimes, such as water regulation or abstraction, will reduce flooding and hence floodplain subsidies to the river. This is likely to have significant impacts on river productivity. 
Extra Keywords: fish, algal production, bacterial production, waterhole

\section{Introduction}

The flood-pulse concept argues that floods are the major force controlling biota in river-floodplain systems (Junk et al. 1989). As a result of lateral river-floodplain exchanges, the bulk of riverine animal biomass is derived directly or indirectly from production on the floodplain, rather than from upstream transport of organic matter. This is because fish and other aquatic organisms move onto the floodplain to exploit food sources during floods. As the flood waters recede, the newly produced animal biomass returns to the main river channel (Balcombe et al. 2005; Lewis et al. 2001). The floodplain is termed the 'aquatic/terrestrial transition zone' because it alternates between aquatic and terrestrial. Therefore during flooding, a floodplain can be defined as 'aquatic'.

Some studies in tropical floodplain-river systems which flood seasonally, such as the Amazon, have shown that many fish species utilize components of floodplain plants, such as pollen, fruits and seeds (Junk et al. 1989). During non-flooding periods when food availability decreases, periods of fasting may occur with a reduction in the fat content of fish. However, fish may continue to use pollen, fruits, seeds and terrestrial insects that fall in the water. Other studies in tropical floodplain rivers have shown that phytoplankton and periphyton can also be important contributors to secondary production, with fish using the main channel primarily for migration and dispersal (Lewis et al. 2000). 
Much of the work on floodplain rivers has been done on systems with a seasonally predictable flow regime. Less well studied are the other extreme of the hydrological floodplain river spectrum, dryland rivers, such as those in the Lake Eyre basin in central Australia. They have highly variable and unpredictable hydrological regimes with infrequent, but extensive flooding of adjacent arid floodplains (Puckridge et al. 1998; Puckridge et al. 2000). Between these flood events, rivers have little or no flow, resulting in fragmented waterways of disconnected waterholes. Indeed, dryland floodplain-river systems in central Australia have more variable flow regimes than many other arid rivers throughout the world (Puckridge et al. 1998; Knighton and Nanson 2001). The wetting and drying process drives ecological change (Stanley and Fisher 1997). Although research on floodplain rivers has generally focussed on tropical systems, dryland rivers are associated with $60 \%$ of the world's arid and semiarid land area.

Unlike some tropical floodplain-river systems, fish diets during flooding in dryland river systems may not be dominated by terrestrial plant material, such as fruits and seeds. A study of fish in an Australian dryland river-floodplain system during flood found that diets were typically dominated by algae, aquatic dipterans, zooplankton and other aquatic fauna (Balcombe et al. 2005). As such the diet of fish during the flood was similar to that during low flow conditions.

Studies of dryland rivers have highlighted the importance of algal production on the floodplain during floods, and the importance of within-river algal production during low or no-flow conditions to fuel fish production (Bunn et al. 2003; Pease et al. 2006; Fellows et al. 2007). However the contribution of floodplain production to 
the river remains unknown. Many dryland rivers are subject to flow regulation to provide water for agriculture and other human needs. This has resulted in a reduction in flooding events and hence floodplain subsidies to rivers. Although the scale of this subsidy is poorly understood, Kingsford et al. (2004) for example, found higher waterbird densities in unregulated systems.

This study therefore sought to quantify the contribution of floodplain carbon to within-river production in an unregulated dryland river in a period of some months after a flooding event. The approach taken was to combine measures of food web linkages, based on stable isotope signatures, and biomass estimates of trophic levels, in the waterhole and on the floodplain, with carbon rate process data for the bacterial and algal communities. This allowed the development of a carbon budget to quantify the relative importance of carbon pathways within the waterhole, and to link these to the floodplain.

\section{Materials and Methods}

Study site

The study sites were located near the township of Windorah on Cooper Creek (S $25^{\circ} 428$, E $142^{\circ} 734$ ), a dryland river in south-western Queensland, Australia. A large waterhole, called Murken, and the adjacent floodplain were sampled during the study (Fig. 1). The semi-arid to arid catchment covers $296,000 \mathrm{~km}^{2}$. There is a narrow strip of riparian vegetation along watercourses consisting of woody vegetation, ie. River Red Gum (Eucalyptus camaldulensis), Coolibah (E. coolibah), and Melaleuca (Melaleuca linariifolia) (Bunn et al. 2003). Waterhole banks are typically steep resulting in considerable shading from riparian vegetation. 
Average daily maximum temperatures are $18-24^{\circ} \mathrm{C}$ in July (winter) and $36-39^{\circ} \mathrm{C}$ in January (summer). Cooper Creek has highly variable and episodic flow patterns with average annual precipitation in the catchment of $400 \mathrm{~mm}$. Based upon 50 years of records (1939-1988), the average discharge at Windorah is $3.3 \mathrm{ML} \mathrm{y}^{-1}$ (Balcombe et al. 2007). However, with inter-annual rainfall being highly unpredictable, there have been extended periods of no flow and several high discharge flood events in recent times. For example, an analysis of the 50 years of Cooper Creek flow records revealed 154 no flow spells, 84 floods (> 20,000 ML d ${ }^{-1}$ ) and 197 flow pulses (220,000 $\mathrm{ML} \mathrm{d}^{-1}$ ) (Bunn et al. 2006a).

Murken waterhole is one of many located within the complex anastomizing channel system that typifies the Cooper Creek Catchment. The waterhole has a full bank volume is $9.5 \mathrm{~km}$ long, and has an area of $1.30 \mathrm{~km}^{2}$. Basin morphology was determined using high-resolution aerial photographs, and surveys (Hamilton et al. 2005). The survey included 3 cross-sections and 1 long section and from this the average slope was calculated. Unlike many of the waterholes, Murken contains water most of the time, with the hydrology being dominated by evaporative water loss (Hamilton et al. 2005).

In January 2004, the study sites were inundated by a large flood (discharge peaking at 775,000 $\mathrm{ML} \mathrm{d}^{-1}, 13,500 \mathrm{~km}^{2}$ inundated) and all Cooper Creek waterholes were hydrologically reconnected (Balcombe et al. 2007). The floodplain surrounding Murken waterhole was inundated for 38 d from 14 January to 21 February 2004. The study was conducted on the floodplain. Fish and invertebrate biomass, stable isotope 
signatures of biota and physico-chemical parameters were measured on the floodplain from 24 to 27 January 2004.

The waterhole was then sampled on three occasions post-overbank flow: 10 - 13 March, 12 - 15 June and 23 - 25 October 2004. In March, Murken waterhole had just recently been disconnected from upstream and downstream waterholes. In May there was a minor flow event which reconnected Murken to adjacent waterholes, but the water level did not reach the floodplain. Between June and October, the waterhole had diminished in size due to the lack of rainfall and flow events. Water depth was highly variable with time and across the waterhole, but for areal calculations, depths were standardized to the deepest location adjacent to Site 2 (see below). Fish and invertebrate biomass, stable isotope signatures of biota, carbon rate processes and physico-chemical parameters were measured in the waterhole on each occasion.

\section{Sampling in the waterhole}

\section{Water quality parameters}

Ambient diel water temperatures and dissolved oxygen concentrations were recorded using a data-logger (TPS Y-82) at site 1 at depths of 10 and $80 \mathrm{~cm}$. For the measurement of total suspended solids, replicate water samples were collected at site 1, filtered onto pre-combusted and pre-weighed glass fibre filters (GF/F) and weighed after drying in an oven at $60^{\circ} \mathrm{C}$.

Subsamples of water from both the surface and bottom at each site in the waterhole were frozen for total nitrogen and phosphorus analysis. Subsamples (June and October 2004 only) were also filtered through $0.45 \mu \mathrm{m}$ (pore size) membrane 
filters and frozen for subsequent analysis of soluble nutrients using standard colorimetric methods (American Public Health Association 1995). Subsamples of water were also collected and analyzed for alkalinity (American Public Health Association 1995).

\section{Algal measures in the water column and sediment}

Measures of algal production $\left({ }^{14} \mathrm{C}\right.$-bicarbonate incubations) and biomass (chlorophyll $a$ ) in the water column and sediment were also conducted at three locations within the waterhole. For sediment measures, three types of substrate were chosen: Site 1 had a gradually sloping sand substrate, Site 2 had a steep slope and muddy substrate, and Site 3 had a steeper slope and coarser substrate than Site 2. These sites spanned half the length of the waterhole.

For the watercolumn, water was collected from the deepest water in three sites within the waterhole adjacent to the sediment sampling sites. Water samples were collected mid-morning from the surface using buckets, and from the bottom using an inverted bottle lowered to the bottom, then filled. Subsamples of water were taken from these buckets for all analyses.

Phytoplankton production was measured using radioactively labelled bicarbonate $\left({ }^{14} \mathrm{C}-\mathrm{HCO}_{3}^{-}\right)$(Parsons et al. 1984). ${ }^{14} \mathrm{C}-\mathrm{HCO}_{3}^{-}$was added to triplicate polycarbonate bottles covered in shadecloth mimicking 100\%, 50\%, 30\%, $10 \%$ and $0 \%$ of surface irradiance. Ambient light intensity and profiles through the water column were measured at each site (photosynthetically active radiation, Licor Li-1400) to determine the light levels for the ${ }^{14} \mathrm{C}$ incubations. Samples were incubated and 
processed using methods developed for an adjacent waterhole (Fellows et al. 2007). To measure benthic algal production, ${ }^{14} \mathrm{C}-\mathrm{HCO}_{3}^{-}$was added to triplicate $25 \mathrm{~mm}$ dia. sediment cores in situ at a range of light levels. Incubations and processing was conducted using the methods developed for an adjacent waterhole (Fellows et al. 2007).

Primary productivity was calculated using the equations of Parsons et al. (1984). Water column areal productivity was calculated by integrating primary productivity through the water column based on the ${ }^{14} \mathrm{C}-\mathrm{HCO}_{3}^{-}$incubation data, alkalinity measurements and light profiles through the water column. Areal benthic primary productivity was calculated by integrating the ${ }^{14} \mathrm{C}-\mathrm{HCO}_{3}^{-}$incubation data across the area of sediment corresponding with the range of light levels in the euphotic zone. The area of sediment was determined based on average slope data as outlined above.

For chlorophyll $a$ analysis, duplicate water column samples were filtered onto glass fibre filters (GF/F Whatman) and frozen. Triplicate sediment samples were collected using $30 \mathrm{~mm}$ cores and $5 \mathrm{~mm}$ sliced off the top. This was stored frozen until the sediment and filter samples were sonicated (Branson Sonifier 450), extracted in acetone and absorbance was measured using a spectrofluorometer (Jeffrey and Welshmeyer 1997). In the case of water samples, areal chlorophyll $a$ concentrations were calculated by integrating values over the water depth. For the sediment samples, values were integrated over the region of the sediment that was within the euphotic zone as measured by the distance from the shore that had a light intensity of $1 \%$ of surface irradiance or greater. 


\section{Bacterial measures in the watercolumn and sediment}

Measures of bacterial production (oxygen exchange in domes, ${ }^{3} \mathrm{H}$-thymidine uptake) and biomass (bacterial counts) were also made in the watercolumn and sediment in the waterhole from 10 March 2004 onwards. The same sites were chosen as for the algal productivity and biomass measures.

Bacterioplankton production was calculated by measuring the incorporation of radioactive thymidine [methyl- ${ }^{3} \mathrm{H}$ ] into bacterial DNA (Parsons et al. 1984). Incubations and processing was conducted using the methods developed for an adjacent waterhole (Fellows et al. 2007). Bacterial production was calculated using the equations of Parsons et al. (1984). Benthic bacterial production could not be calculated using the thymidine method due to the interference from fine sediment particles.

Benthic respiration, as a measure of bacterial production rates, was quantified by measuring changes in dissolved oxygen (DO) concentration over 6 to $8 \mathrm{~h}$ after dark in clear dome-shaped Perspex chambers (29.5 cm dia., 25 cm height) inserted $\sim 0.10 \mathrm{~m}$ into the sediment in the euphotic zone (Bunn et al. 2003). The thick clay substrate (Fagan and Nanson 2004) provided a reliable seal at these depths of insertion (Bunn et al. 2003; Fellows et al. 2007). Incubations and processing was conducted using the methods developed for the adjacent waterhole (Fellows et al. 2007). Changes in dissolved oxygen over time were multiplied by chamber volume and divided by substrate surface area to obtain areal rates of oxygen flux. A 1:1 molar conversion ratio from oxygen to carbon was assumed in order to convert respiration rates to units of carbon (Chapra 1997). 
For bacterial biomass estimates, subsamples of water collected from sites 1, 2 and 3 were preserved with formalin and stored at $4^{\circ} \mathrm{C}$ until analyzed in the laboratory. Samples were sonicated, stained with acridine orange and filtered onto $0.2 \mu \mathrm{m}$ (Poretics) polycarbonate filters (Hobbie et al. 1977). Bacteria were then counted using an epifluorescence microscope (Leica DM4000) at 1000x magnification. Bacterial cell size was measured using a micrometer. Benthic bacterial densities could not be quantified due to the high level of interference from fine sediment particles.

$20 \mathrm{~L}$ of water was collected from Murken waterhole two years after the flood, in January 2006, to determine the carbon content of the bacteria, since literature values vary considerably. This was used to calculate the total bacterial biomass (Table 3). Bacterial size was similar between January 2004 and January 2006 so the assumption was made that the carbon content of bacteria did not change substantially. In the laboratory, $250 \mathrm{ml}$ sub-samples were centrifuged at $5000 \mathrm{rpm}$ for $30 \mathrm{~min}$. The supernatant was discarded and the pellet collected and spun using silica gradient centrifugation using Ludox at a density of $1.59 \mathrm{~g} \mathrm{~cm}^{-3}$ (Ducklow 2000). Bacteria concentrated at the silica/sample interface were pipetted off. The bacteria were then enumerated using the methods described above before being freeze dried. Percentage carbon, nitrogen and stable isotope ratios were measured with a continuous-flow isotope-ratio mass spectrometer (Micromass Isoprime Eurovector EA3000, Manchester). The average carbon content per cell of bacteria was then calculated using carbon content, cell density and bio-volume. 


\section{$\underline{\text { Fish and invertebrate measures }}$}

Fish and prawns (predominantly Macrobrachium australiense) were collected in Murken waterhole in March, June and October 2004. The biomass was calculated from three replicate seine net trawls (20 x $2 \mathrm{~m}, 12 \mathrm{~mm}$ mesh) in the littoral margins by encircling the full area of the seine. All fish were individually weighed and summed together for the bulk biomass. As small prawns were likely to escape the seine net, three replicate small drag net ( $2.5 \times 1.1$ wide, $2.2 \mathrm{~m}$ deep, $1 \mathrm{~mm}$ mesh) tows were done over $10 \mathrm{~m}$ as an additional measure of prawn biomass. Fish and prawn standing stocks was calculated by summing the total biomass from the three seines (and three drags) divided by the total area sampled and converted to $\mathrm{kg} \mathrm{ha}^{-1}$.

\section{Stable isotopes in the biota}

Samples of benthic algae $(n=5)$, benthic particulate matter $(n=2)$, zooplankton ( $\mathrm{n}=8$ ), Macrobrachium (23 individuals), the three most dominant fish species (89\% of total biomass), Spangled Perch (Leiopotherapon unicolour, 20 individuals), Silver Tandan (Porochilus argenteus, 46 individuals) and Bony Bream (Nematalosa erebi, 33 individuals), unidentified smelt (5 individuals), and notonectids ( $n=4$ ) were collected in the waterhole in March, June and October for $\delta^{13} \mathrm{C}$-carbon and percentage carbon analysis. Benthic algae, benthic particulate matter (top $1 \mathrm{~cm}$ ) and macroinvertebrates were collected by hand. Zooplankton was collected by towing a plankton net ( $250 \mu \mathrm{m}$ mesh size) just below the water surface. Fish and Macrobrachium were collected as described above. All samples were frozen until processed in the laboratory. 
In the laboratory, benthic algae, benthic particulate matter and zooplankton were thawed and rinsed in distilled water. Benthic particulate matter was screened through a $250 \mu \mathrm{m}$ screen to give course particulate organic matter (CPOM). Muscle tissue was removed from Macrobrachium and fish samples. Samples were dried at $60^{\circ} \mathrm{C}$ in a drying oven, ground and processed using a mass spectrometer (Bunn et al. 2003).

\section{Floodplain sampling}

In January 2004, three fyke nets were deployed at four locations on the floodplain in the vicinity of Murken waterhole for fish biomass estimates (Fig. 1). Fish were processed using the same methods as for the waterhole.

Samples of benthic algae $(n=1)$, benthic particulate matter $(n=1)$, zooplankton (n = 7), Macrobrachium (13 individuals), the three most dominant fish species (89\% of total biomass), Spangled Perch (Leiopotherapon unicolour, 4 individuals), Silver Tandan (Porochilus argenteus, 3 individuals) and Bony Bream (Nematalosa erebi, 5 individuals), unidentified smelt (10 individuals), and notonectids $(n=7)$ were collected on the floodplain during the January flood for $\delta^{13} \mathrm{C}$-carbon and percentage carbon analysis. Samples were collected and processed as per the waterhole samples.

Surface water was also collected from six sites on the floodplain in January 2004 for total suspended solids, alkalinity, total nitrogen and phosphorus. Samples were analyzed using the methods described above. 
In order to determine the contribution of carbon sources within the waterhole to productivity, a carbon budget was compiled (Table 3). This included standing stocks of algae, bacteria, benthic organic matter, litterfall, fish, as well as productivity rates for algae and bacteria. For determination of phytoplankton and benthic algal carbon, the mean chlorophyll $a$ concentration in the water column on each sampling trip was multiplied by a carbon:chlorophyll $a$ ratio of 25 (Zonneveld 1998). For bacterioplankton, the cell counts were multiplied by the measured carbon content of the bacteria (47 $\mathrm{fg}$ cell $^{-1}$, see Method above).

For determination of rates of carbon fixation by phytoplankton and benthic algae, depth-integrated ${ }^{14} \mathrm{C}-\mathrm{HCO}_{3}{ }^{-}$incubation data was used. In the case of benthic algal data, it was assumed that $10 \%$ of the total waterhole bottom area was in the euphotic zone. This was based on measurements of the euphotic depth, the area of the waterhole and slope measurements (Hamilton et al. 2005). Carbon utilization by bacterioplankton, was measured using ${ }^{3} \mathrm{H}$-thymidine data while for benthic bacteria,, oxygen depletion rates measured in Perspex domes were converted to carbon utilization rates. The carbon content of coarse benthic organic matter was determined when samples were analyzed for stable isotope ratios (see above).

Fish biomass was multiplied by the carbon content of fish, which was determined by continuous-flow isotope-ratio mass spectrometer, to derive a carbon biomass for fish. Reduction in measured fish biomass between March and June 2004 was assumed to have occurred at a linear rate to give a carbon reduction rate for fish in mg $\mathrm{C} \mathrm{m} \mathrm{m}^{-2} \mathrm{~d}^{-1}$ 


\section{Floodplain contribution to waterhole carbon}

The contribution of floodplain carbon to the waterhole, via fish, was calculated for the three dominant fish species (89\% of the total fish biomass) (Table 4). As it was not possible to determine what proportion of fish on the floodplain contributed to the biomass in Murken waterhole, an alternative approach based on knowledge of the fish species and size distribution was used. The biomass of fish on the floodplain that returned to Murken waterhole was calculated by subtracting the measured biomass of fish in the waterhole (March) from the calculated biomass of the same number of fish when on the floodplain.

To examine the influence of floodplain use on fish growth and subsequent carbon transfer into Murken waterhole in March 2004, size frequency histograms were compared between fyke net catches on the floodplain to those in the waterhole (Balcombe et al. 2007). In March 2004, three fyke nets were deployed at three random locations within Murken waterhole. Fish collected in the fyke nets were placed into a $25 \mathrm{~L}$ holding tub, their standard length measured to the nearest $\mathrm{mm}$ and each weighed to the nearest gram. Fish were subsequently released at point of capture, with each net fully processed before starting on the next one (Arthington et al. 2005). Biomass gained by each species was estimated by comparing length gain from the histograms to expected weight gain from length-weight relationships for fish in Cooper Creek. Assuming no mortality between January and March, the theoretical biomass of fish in January could then be calculated, as a proportion of the biomass in March. 
Previous studies have shown that food was abundant and available within days of inundation on this floodplain (Balcombe et al. 2005); therefore $38 \mathrm{~d}$ was used as the period of feeding on the floodplain. Daily food intake rates during the flood were estimated for fish in the relevant size categories, i.e. larval, juvenile, adult, and thus the total food intake of fish when on the floodplain was calculated (Tacon 1988; Glencross et al. 2006). From this, a carbon incorporation value from the floodplain to Murken waterhole was calculated.

\section{Results}

Physico-chemical environment

Maximum and minimum daily water temperatures in Murken waterhole were highest in March (30.8 and $26.0^{\circ} \mathrm{C}$ respectively) and lowest in June (20.8 and $17.9^{\circ} \mathrm{C}$ respectively) (Table 1). Minimum and maximum daily dissolved oxygen (DO) concentrations were lowest in March and highest in June, and concentrations were lower at $80 \mathrm{~cm}$ deep (near the sediment surface) than at $10 \mathrm{~cm}$ deep. The lowest DO concentrations at $80 \mathrm{~cm}$ deep were $3.94 \mathrm{mg} \mathrm{L}^{-1}$. The waterhole was highly turbid (80 $-420 \mathrm{mg} \mathrm{L}^{-1}$ total suspended solids) with a low euphotic depth $(0.15-0.20 \mathrm{~m})$ compared with the total water depth of 2.4 to 2.9 m. Turbidity was highest in March 2004, one to two months after the flood in January 2004.

Total nitrogen and phosphorus concentrations ranged between 0.84 - 1.50, and 0.26 - $0.48 \mathrm{mg} \mathrm{L}^{-1}$ respectively across the three sampling occasions in the waterhole (Table 1). Dissolved nutrient concentrations were only measured in June and October 2004. Mean phosphate, oxides of nitrogen and ammonium concentrations ranged from 0.065 to $0.111,0.455$ to 0.490 , and 0.015 to $0.020 \mathrm{mg} \mathrm{L}^{-1}$ respectively. The total 
suspended solids, total nitrogen and total phosphorus concentrations on the floodplain were 288, 1.18 and $0.43 \mathrm{mg} \mathrm{L}^{-1}$ respectively which was within the range of values in Murken waterhole.

Algal measures in the water column and sediment

Depth-integrated phytoplankton biomass, as measured by chlorophyll $a$ concentrations in the water, ranged from $2.05 \pm 0.29$ to $10.42 \pm 0.93 \mathrm{mg} \mathrm{m}^{-2}$ (Table 1). In June, Site 2 had substantially higher concentrations (38 $\mathrm{mg} \mathrm{m}^{-2}$ ) at the surface due to stratification of phytoplankton cells under calm conditions. Areal primary productivity of phytoplankton, as measured by ${ }^{14} \mathrm{C}$ incorporation, was highly variable between sites. March was the most variable period (290.2 $\left.\pm 186.1 \mathrm{mg} \mathrm{C} \mathrm{m}^{-2} \mathrm{~d}^{-1}\right)$ due to substantially higher values at Site 2 (Fig. 2a).

Benthic chlorophyll $a$ concentrations within the euphotic zone ranged from 11.97 $\pm 1.39 \mathrm{mg} \mathrm{m}^{-2}$ in March 2004, to $57.08 \pm 70.87$ and $54.29 \pm 36.87 \mathrm{mg} \mathrm{m}^{-2}$ in June and October respectively (Table 1). Overall, benthic primary productivity was highly variable between sites (Fig. 2a), with similar areal rates of primary productivity to the water column.

Bacterial measures in the watercolumn and sediment

Areal bacterial densities in the water column ranged from 33.0 to $52.6 \times 10^{11} \mathrm{~m}^{-2}$ (Table 1). Benthic bacterial densities could not be quantified due to the high level of interference from fine sediment particles. 
Depth-integrated, areal bacterial productivity rates in the water column, as

measured using the ${ }^{3} \mathrm{H}$-thymidine method, was highly variable, particularly at site 1 in June (Fig. 2b). Benthic bacterial productivity, as measured using oxygen fluxes, was less variable than water column productivity i.e. 195 - $269 \mathrm{mg} \mathrm{C} \mathrm{m}^{-2} \mathrm{~d}^{-1}$ (Fig. 2b).

\section{Fish and prawn biomass}

Fish biomass was variable through time in the waterhole but highest in March (1130 $\mathrm{kg} \mathrm{ha}^{-1}$ ), 2 to 3 weeks following disconnection of Murken waterhole from the channel network (Table 2). The lowest biomass was in June (210 kg ha ${ }^{-1}$ ), three months after disconnection. There was a small increase in fish biomass in October, possibly due to the recruitment of juvenile fish, namely bony bream (N. erebi), spangled perch (L. unicolor) and silver tandans (P. argenteus) (S. Balcombe, unpubl. data). Prawn (Macrobrachium) biomass, quantified using a seine net, was higher in March and October than June (Table 2). The drag net, which had a smaller mesh size, gave the highest biomass in March than in either June or October. The discrepancy in biomass between the mesh probably indicates the presence of larger bodied prawns that were able to escape the smaller net.

Stable isotope analyses

Mean $\delta^{13} \mathrm{C}$-carbon ratios were compared for the same groups (algae, CPOM, macroinvertebrates (Notonectids), Macrobrachium and fish) in the waterhole in the combined sampling times (March, June and October 2004) with the floodplain in January 2004. Across all groups, the waterhole ratios was significantly correlated with the floodplain $\left(\mathrm{R}^{2}=0.84, P<0.005\right.$, Fig. 3). 


\section{Carbon budget}

The carbon budget constructed for Murken waterhole showed that the largest carbon pool in the waterhole was fish, peaking in March 2004 (11,879 $\left.\mathrm{mg} \mathrm{C} \mathrm{m}^{-2}\right)$ with an $80 \%$ reduction between March and June when the waterhole was disconnected (2230 $\mathrm{mg} \mathrm{C} \mathrm{m}^{-2}$ ) (Table 3). A daily reduction of $107 \mathrm{mg} \mathrm{C} \mathrm{m}^{-2} \mathrm{~d}^{-1}$ was calculated, assuming a linear reduction in biomass between March and June. Recruitment of fish between June and October increased the fish biomass to levels equivalent to typical dry-season levels (pre-flood) encountered in this region (Arthington et al. 2005).

Rates of autotrophic and heterotrophic production were variable within sampling occasions and between occasions but with heterotrophic production generally higher than autotrophic production overall.

A carbon incorporation value from the floodplain to Murken waterhole of 5220 $\mathrm{mg} \mathrm{C} \mathrm{m}{ }^{-2}$ (of Murken waterhole area) in the form of fish biomass input was calculated (Table 4). This compares with a total carbon pool of fish in the waterhole in March of $11879 \mathrm{mg} \mathrm{C} \mathrm{m}^{-2}$ and a primary producer carbon pool of $571 \mathrm{mg} \mathrm{C} \mathrm{m}^{-2}$ (Table 3).

\section{Discussion}

Based on this study, we calculated that theoretically $50 \%$ of the carbon in the waterhole fish came from the floodplain. As such, floodplain inputs to the waterhole have a significant role in fuelling waterhole production, at least in the short term. The food requirements of these fish in the waterhole in March 2004, just after disconnection, were calculated. Assuming a daily food intake of $3 \%$ of body weight, the daily intake requirements of fish in March was calculated to be $360 \mathrm{mg} \mathrm{C} \mathrm{m}^{-2} \mathrm{~d}^{-1}$ 
(Tacon 1988; Glencross et al. 2006). The dominant fish species (89\% of biomass) were Spangled Perch (Leiopotherapon unicolor), Silver Tandan (Porochilus argenteus) and Bony Bream (Nematalosa erebi) which, when in waterholes, feed primarily on primary producers, i.e. algae, and first order consumers, i.e. zooplankton, detritus, and other invertebrates (Balcombe et al. 2005). Primary productivity at this time was 300 to $500 \mathrm{mg} \mathrm{C} \mathrm{m}^{-2} \mathrm{~d}^{-1}$. Given the inefficiencies of trophic transfer of carbon, the fish daily carbon requirements are unlikely to be met with carbon inputs from primary productivity.

In support of this, parallel studies in this waterhole showed decreasing lipid levels in fish post-flood, reflecting a decrease in nutritional status over time (R. Cunjack unpubl. data). Furthermore, there was a high incidence of stress-related fungal lesions in March. Other studies in tropical floodplain systems have shown that fish fasting may occur during periods of low or falling water levels, possibly due to reduced food availability, resulting in a lower fat content (Junk et al. 1989). Therefore reduction of fish biomass in our study was most likely to be due to fish mortality as a result of starvation. Low anoxia during flooding has also been shown to cause mass fish mortality (Hamilton et al. 1997). However in our study, minimum oxygen concentrations remained high at all three sampling occasions.

The fish are likely to have provided a carbon source to the waterhole, but may also have been exported via bird predation. Waterbird numbers can be high, but highly variable, in arid areas of Australia. Most species typically move large distances following flooding on floodplains and lakes, and hence accessing food (Roshier et al. 2002). It would therefore be expected that waterbird numbers would be high during 
flooding but most birds would follow the flooding as it moved downstream, over a period of some months, to Lake Eyre. A previous survey of waterbirds at Cooper Creek found that although numbers can be very high, the dominant species were not piscivorous (Kingsford et al. 1999). Additionally high numbers of piscivorous birds were not observed on Murken waterhole during our sampling trips. Therefore it seems unlikely that the reduction in fish biomass could be explained primarily by waterbird predation.

In Cooper Creek, all indigenous fish species, with one possible exception (Cooper Creek Tandan, Neosiluroides cooperensis), make use of the inundated floodplains as juveniles and maturing individuals and/or as spent (post-spawning) adults (Arthington et al. 2005; Balcombe et al. 2007). A previous study has shown that when these fish inhabit the floodplain during flood events, their diet had a large aquatic component, i.e. algae, aquatic dipterans, other aquatic fauna and zooplankton, similar to the diet when fish were in the contracted waterhole (Balcombe et al. 2005). Our study found a similarity between the floodplain and waterhole $\delta^{13} \mathrm{C}$ signatures in fish, and that of the lower trophic levels, also consistent with fish consuming a diet from similar sources in both the floodplain and waterhole.

This contrasts with some studies of tropical floodplain-river systems where many fish species may utilize a distinctly different diet during floods than during non-flood periods. In the Amazon floodplain-river complex, for example, fish feed on floodplain plant parts, such as pollen, fruits and seeds, as well as detritus (Junk et al. 1989). However, another study in the Orinoco floodplain-river complex found that 
during flooding, phytoplankton and periphyton were the main source fuelling secondary production (Lewis et al. 2000).

Measures of primary productivity on the Cooper Creek floodplain during a flood event found that the amount of benthic algal carbon produced on the floodplain during a single day of inundation was equivalent to over 80 years of aquatic production in the permanent waterholes of the Cooper Creek system during the dry (Bunn et al. 2006b). The duration of flooding and inter-flood intervals are therefore critical in determining the resulting effects on floodplain productivity and biogeochemical processes. Valett et al. (2005) found that flooding and inter-flood intervals affected respiration rates, anoxia formation and dissolved organic carbon release on floodplains during flooding in a semi-arid American river.

Rates of heterotrophic production in this study were high relative to other Australian river studies (Rees et al. 2005; Vink et al. 2005), while rates of autotrophic production were low possibly due to the high turbidity limiting light availability (Fisher et al. 1982; Uehlinger and Brock 2005). The measures of microbial respiration were limited to aerobic respiration, and did not account for anaerobic respiration. However, minimum daily dissolved oxygen concentrations near the sediment surface did not go below $3.94 \mathrm{mg} \mathrm{L}^{-1}$. Additionally, there was no evidence of highly depleted $\delta^{13} \mathrm{C}$-carbon signatures in the sediment in Murken waterhole which would be indicative of methane production. This lack of methane production has previously been demonstrated in Cooper Creek waterholes (Bunn et al. 2003). Given that autotrophic production was insufficient to provide the carbon requirements for 
heterotrophic production, it is likely that organic carbon in either dissolved or particulate form, resulting from fish mortality, was a significant source.

Leaf litter from riparian vegetation is often purported to be an important source of carbon for rivers. It was not directly measured in our study but a study of dryland rivers in Arizona found values of only $2 \mathrm{mg} \mathrm{C} \mathrm{m}^{-2} \mathrm{~d}^{-1}$ (Jones et al. 1997), while a review of carbon sources in inland Australian rivers found values ranging from 0.2 to $0.6 \mathrm{~g} \mathrm{C} \mathrm{m}^{-2} \mathrm{~d}^{-1}$ (Robertson et al. 1999). If these rates of input were comparable with our study, leaf litter would be a minor carbon input. Additionally, riparian species in arid zones, such as those in our study, have been shown to produce litter of poor nutritional value (Bunn 1988). However, significant amounts of dissolved organic carbon can be released when leaves first become wet, and the slow breakdown can provide a sustained source of organic carbon to the system (Francis and Sheldon 2002).

We hypothesize a shift in the dominant carbon sources fuelling the food web in Murken waterhole with changes in hydrology. This can be characterized diagrammatically with the size of the text indicating the relative dominance of each process (Fig. 4). Previous studies have shown that in the pre-flood period, assuming that there had been an extended period of low or no flow with relatively low fish biomass, consistent with the food web being sustained by a benthic algal source (Bunn et al. 2003). Benthic algal sources have also been shown to be the dominant source of carbon for the food web in an arid river in USA (Pease et al. 2006). It is predicted that fish biomass in the waterhole would decrease as some fish moved onto the floodplain to feed. Post-flood, fish density is likely to increase temporarily as fish 
from the floodplain became concentrated in the isolated waterhole. Thereafter the productivity of the system was insufficient to support the high biomass resulting in mass mortality.. This increased heterotrophic production for some months until a new equilibrium is reached. The time taken to return to pre-flood conditions is dependent on the scale and duration of the flooding event.

The findings of this study are consistent with the flood pulse concept which argues that floods are important in the dynamics of floodplain-river ecosystems as a result of lateral river-floodplain exchanges of carbon (Junk et al. 1989). However in our study this was not via the classically established routes where terrestrial sources of carbon, in the form of detrital matter, accumulate in the waterhole, or alternatively where terrestrial plant sources, e.g. fruits, provide food for fish on the floodplain. Instead, in this system the lateral exchange was, in large part, in the form of fish biomass that had accumulated on the floodplain while consuming aquatic food sources.

Australia has many dryland rivers, including those in the dry tropics, which have extensive inundated floodplains during rainy periods. Although many of these systems are poorly understood, it is likely that floodplains provide carbon subsidies to the rivers, as is the case in our study. It would be expected that fish mortality would be a regular occurrence during the retraction of floodplain waters, provided the period of flooding was sufficient for aquatic food sources to flourish, and for fish to reproduce and feed.

Most floodplain rivers throughout the world are highly modified due to regulation or diversion of flow (Lewis et al. 2000). This is particularly true in the Northern 
Hemisphere, and is increasingly the case in the Southern Hemisphere, including Australia. Removing floods can have effects not only on individual species but flowon effects on the whole foodweb (Wootton et al. 1996). A number of studies have highlighted the importance of flooding on the productivity of the biota (Maher and Carpenter 1984; Jenkins and Boulton 2003; Kingsford et al. 2004; Shiel et al. 2006).

Dryland rivers are particularly vulnerable to these modifications due to the highly episodic and unpredictable nature of flooding events. The extended dry periods can be critical phases where aquatic biota have to survive in shrinking, disconnected waterholes (Young and Kingsford 2006). Increased dry periods due to reduced flows as a result of water abstraction and/or changes in rainfall patterns due to climate change is therefore likely to have two major effects: a reduction in the carbon subsidies from the floodplain to fuel production in the river; and an increased likelihood of loss of aquatic habitat. 


\section{Acknowledgments}

We would like to thank: Angela Arthington, Rick Cunjack, James Fawcett, Wade Hadwen, Mavourneen Lutton and Angelene Wright for assistance with field work, Jon Marshall for physico-chemical data, Dan Wruck for nutrient analyses, Susie Green for bacterial counts, Rene Diocares for stable isotope analyses, Peter Pollard for helpful discussions on bacterial productivity, and Wade Hadwen and Vanessa Fry for useful comments on the manuscript. Our research was conducted under Queensland Fisheries Permit PRM00157K and Griffith University Animal Experimentation Ethics Committee permit AES/03/02. Funding was provided by the Cooperative Centre for Freshwater Ecology and the Australian Rivers Institute. 


\section{References}

American Public Health Association. (1995). Standard Methods for the Examination of Water and Wastewater. 20th Edition, (Eds A.E., Greenburg, L.S. Clesceri and A.D, Eaton) (American Public Health Association: Washington, D.C.).

Arthington, A.H., Balcombe, S.R., Wilson, G.A., Thoms M.C. and Marshall J. (2005) Spatial and temporal variation in fish-assemblage structure in isolated waterholes during the 2001 dry season of an arid-zone floodplain river, Cooper Creek, Australia. Marine and Freshwater Research 56, 25-35.

Balcombe, S.R., Bunn, S.E., McKenzie-Smith, F.J. and Davies, P.M. (2005) Variability of fish diets between dry and flood periods in an arid zone floodplain river. Journal of Fish Biology 67, 1552-1567.

Balcombe, S.R., Bunn, S.E., Arthington, A.H., Fawcett, J.H., McKenzie-Smith, F.J. and Wright, A. (2007) Fish larvae, growth and biomass relationships in an Australian arid zone river: links between floodplains and waterholes. Freshwater Biology 52, 2385-2398.

Bunn, S.E. (1988) Processing of leaf litter in a northern Jarrah forest stream, Western Australia: I. Seasonal differences. Hydrobiologia 162, 201-210.

Bunn, S.E., Davies, P.M. and Winning, M. (2003) Sources of organic carbon supporting the food web of an arid zone floodplain river. Freshwater Biology 48, $619-635$.

Bunn SE, Thoms MC, Hamilton SK, Capon SJ (2006a). Flow variability in dryland rivers: boom, bust and the bits in between. River Research and Applications 22, 179-186

Bunn, S.E., Balcombe, S.R., Davies, P.M., Fellows, C.S. and McKenzie-Smith, F.J. (2006b) Aquatic productivity and food webs of desert river ecosystems. In : 
‘Ecology of Desert Rivers’ (Ed R.T. Kingsford) (Cambridge University Press : Cambridge). pp. 76-99.

Chapra, S.C. (1997) Surface Water-Quality Modeling. (WCB/McGraw-Hill: New York).

Ducklow, H. (2000) Bacterial production and biomass in the oceans. In: 'Microbial Ecology of the Oceans’ (Ed D.L. Kirchman) (John Wiley: New York).

Fagan, S.D. and Nanson, G.C. (2004) The morphology and formation of floodplainsurface channels, Cooper Creek, Australia. Geomorphology 60, 107-126.

Fellows, C.S., Wos, M.L., Pollard, P.C. and Bunn, S.E. (2007) Ecosystem metabolism in a dryland river waterhole. Marine and Freshwater Research 58, 250-262.

Fisher, S.G., Gray, L.J. Grimm, N.B. and Busch, D.E. (1982) Temporal succession in a desert stream ecosystem following flash flooding. Ecological Monographs 52, 93-110.

Francis, C. and Sheldon, F. (2002) River Red Gum (Eucalyptus camaldulensis Dehnh.) organic matter as a carbon source in the lower Darling River, Australia.

Glencross, B.D. (2006) Nutritional management of barramundi: Lates calcifer - A review. Aquaculture Nutrition 12, 291-309.

Hamilton, S.K., Sippel, S.J., Calheiros, D.F. and Melack, J.M. (1997) An anoxic event and other biogeochemical effects of the Pantanal wetland on the Paraguay River. Limnology and Oceanography 42, 257-272.

Hamilton, S.K., Bunn, S.E. Thoms, M.C. and Marshall J.C. (2005) Persistence of aquatic refugia between flow pulses in a dryland river system. Limnology and Oceanography 50, 743-754. 
Hobbie, J.E., Daley, R.J. and Jasper, S. (1977) Use of nuclepore filters for counting bacteria by fluorescence microscopy. Applied and Environmental Microbiology 33, $1225-1228$.

Jeffrey, S.W. and Welshmeyer, N.A. (1997) Spectrophotometric and fluorometric equations in common use in oceanography. In 'Phytoplankton Pigments in Oceanography’ (Eds S.W. Jeffrey, R.F.C. Mantoura, and S.W. Wright) (Monographs on Oceanographic Methodology No.10. UNESCO Publication). Jenkins, K.M. and Boulton, A.J. (2003) Connectivity in a dryland river: Short-term aquatic microinvertebrate recruitment following floodplain inundation. Ecology 84: 2708-2723.

Jones, J.B., Schade, J.D., Fisher, S.C. and Grimm, N.B. (1997) Organic matter dynamics in Sycamore Creek, a desert stream in Arizona, USA. Journal of the North American Benthological Society 16, 78-82.

Junk, W.J., Bayley, P.B. and Sparks, R.E. (1989) The flood pulse concept in riverfloodplain systems. In 'Proceedings of the International Large River Symposium'. (Ed. D.P. Dodge) Canadian Special Publication on Fisheries and Aquatic Science 106, $110-127$.

Kingsford, R.T., Curtin, A.L. and Porter, J. (1999) Water flows on Cooper Creek in arid Australia determine 'boom' and 'bust' periods for waterbirds. Biological Conservation 88, 231-248.

Kingsford, R.T., Jenkins, K.M. and Porter, J.L. (2004) Imposed hydrological stability on lakes in arid Australia and effects on waterbirds. Ecology 85, 2478-2492.

Knighton, A.D. and Nanson, G.C. (2001) An event-based approach to the hydrology of arid zone rivers in the Channel Country of Australia. Journal of Hydrology 254, 102-123. 
Lewis, W.M. Jr, Hamilton, S.K., Lasi, M.A., Rodriguez, M. and Saunders, J.F. III. (2000) Ecological determinism on the Orinoco floodplain. Bioscience 50, 681692.

Lewis, W.M. Jr, Hamilton, S.K., Rodriguez, M., Saunders, J.F. III and Lasi, M.A. (2001) Foodweb analysis of the Orinoco floodplain based on production estimates and stable isotope data. Journal of the North American Benthological Society 20, 241-254.

Maher, M. and Carpenter, S.M. (1984) Benthic studies of waterfowl breeding habitat in south-western New South Wales. II. Chironomid populations. Australian Journal of Marine and Freshwater Research 35: 97-110.

Parsons, T.R., Maita, Y. and Lalli, C.M. (1984) ‘A Manual of Chemical and Biological Methods for Seawater Analysis’. (Pergamon: Oxford).

Pease, A.A., Davis, J.J., Edwards, M S. and Turner, T.F. (2006) Habitat and resource use by larval and juvenile fishes in an arid-land river (Rio Grande, New Mexico). Freshwater Biology 51, 475-486.

Puckridge, J.T., Sheldon, F., Walker, K.F. and Boulton, A.J. (1998) Flow variability and the ecology of large rivers. Marine and Freshwater Research 49, 55-72.

Puckridge, J.T., Walker, K.F. and Costelloe, J.F. (2000) Hydrological persistence and the ecology of dryland rivers. Regulated Rivers and Reservoir Management 16, 385-402.

Rees, G.N., Beattie, G., Bowen, P.A. and Hart, B.T. (2005) Heterotrophic bacterial production in the lower Murray River, south-eastern Australia. Marine and Freshwater Research 56, 835-841. 
Robertson, A.I., Bunn, S.E., Boon, P.I. and Walker, K.F. (1999) Sources, sinks and transformations of organic carbon in Australian floodplain rivers. Marine and Freshwater Research 50, 813-829.

Roshier, D.A., Robertson, A.I. and Kingsford, R.T. (2002) Responses of waterbirds to flooding in an arid region of Australia and implications for conservation. Biological Conservation 106, 399-411.

Shiel, R.J., Costelloe, J.F., Reid, J.R.W., Hudson, P. and Powling, J. (2006) Zooplankton diversity and assemblages in arid zone rivers of the Lake Eyre Basin, Australia. Marine and Freshwater Research 57, 49-60.

Stanley, E.H. and Fisher, S.G. (1997) Ecosystem expansion and contraction in streams. Bioscience 47, 427-435.

Tacon, A.G.J. (1988) 'The nutrition and feeding of farmed fish and shrimp - A training manual. 3. Feeding methods’. (FAO Trust Fund GCP/RLA/075/ITA Project: Rome).

Uehlinger, U. and Brock, J.T. (2005) Periphyton metabolism along a nutrient gradient in a desert river (Truckee River, Nevada, USA). Aquatic Science 67, 507-516.

Valett, H.M., Baker, M.A., Morrice, J.A., Crawford, C.S., Molles, M.C., Dahm, C.N., Moyer, D.L., Thibault, J.R. and Ellis, L.M. (2005) Biogeochemical and metabolic responses to the flood pulse in a semiarid floodplain. Ecology 86, 220-234.

Vink, S., Bormans, M., Ford, P.W. and Grigg, N.J. (2005) Quantifying ecosystem metabolism in the middle reaches of the Murrumbidgee River during irrigation flow releases. Marine and Freshwater Research 56, 227-241.

Wootton, J.T., Parker, M.S. and Power, M.E. (1996) Effects of disturbance on river food webs. Science 273, 1558-1551 
Young, W.J. and Kingsford, R.T. (2006) Flow variability in large unregulated dryland rivers. In 'Ecology of Desert Rivers’ (Ed. R.T. Kingsford) (Cambridge University Press : Cambridge).

Zonneveld, C. (1998) A cell-based model for the chlorophyll $a$ to carbon ratio in phytoplankton. Ecological Modelling 113, 55-70. 
Table 1: Mean (SD) physico-chemical, nutrient and biomass measures (3 sites) in Murken waterhole at the three sampling periods and on the floodplain in January 2004. *Water depth was determined at the deepest point adjacent to Site 2 . Temp $=$ water temperature, $\mathrm{DO}=$ dissolved oxygen, $\mathrm{TSS}=$ total suspended solids, $\mathrm{W} / \mathrm{C}=$ water column, chl $a=$ chlorophyll $a$

\begin{tabular}{|c|c|c|c|c|c|}
\hline Variable & $\begin{array}{l}\text { Depth } \\
\text { (m) }\end{array}$ & \begin{tabular}{|l|} 
Floodplain \\
January ‘04
\end{tabular} & March '04 & June '04 & October'04 \\
\hline Water depth* (m) & & & 2.9 & 2.6 & 2.4 \\
\hline Max daily temp $\left({ }^{\circ} \mathrm{C}\right)$ & 0.1 & & 30.8 & 20.8 & 29.33 \\
\hline Min daily temp $\left({ }^{\circ} \mathrm{C}\right)$ & 0.1 & & 26.0 & 17.9 & 19.57 \\
\hline $\begin{array}{l}\text { Max daily DO (mg L' } \\
\text { 1) }\end{array}$ & 0.1 & & 5.38 & 9.20 & 7.98 \\
\hline Min daily DO $\left(\mathrm{mg} \mathrm{L}^{-1}\right)$ & 0.1 & & 4.71 & 8.61 & 6.12 \\
\hline $\begin{array}{l}\text { Max daily DO (mg L } \\
\text { 1) }\end{array}$ & 0.8 & & 4.60 & 8.13 & 7.08 \\
\hline Min daily DO $\left(\mathrm{mg} \mathrm{L}^{-1}\right)$ & 0.8 & & 3.94 & 7.70 & 4.93 \\
\hline Euphotic depth (m) & & & 0.15 & 0.19 & 0.20 \\
\hline TSS (mg L ${ }^{-1}$ ) (surface) & & 288 & 420 & 80 & 165 \\
\hline Total nitrogen $\left(\mathrm{mg} \mathrm{L}^{-1}\right)$ & & 1.18 & 1.40 & 0.84 & 1.50 \\
\hline $\begin{array}{l}\text { Total phosphorus (mg } \\
\mathrm{L}^{-1} \text { ) }\end{array}$ & & 0.43 & 0.33 & 0.26 & 0.48 \\
\hline Phosphate (mg L ${ }^{-1}$ ) & & & - & 0.065 & 0.111 \\
\hline Oxides of $\mathrm{N}\left(\mathrm{mg} \mathrm{L}^{-1}\right)$ & & & - & 0.455 & 0.490 \\
\hline Ammonium (mg L $\left.{ }^{-1}\right)$ & & & - & 0.015 & 0.020 \\
\hline $\begin{array}{l}\text { Alkalinity } \\
\mathrm{mg} \mathrm{CaCO}_{3} \mathrm{~L}^{-1}\end{array}$ & & 38.8 & 29.5 & 33.5 & 46 \\
\hline $\mathrm{W} / \mathrm{C} \operatorname{chl} a\left(\mathrm{mg} \mathrm{m}^{-2}\right)$ & & & $\begin{array}{l}10.42 \\
(0.93)\end{array}$ & $\begin{array}{l}10.31 \\
(10.91)\end{array}$ & $2.05(0.29)$ \\
\hline
\end{tabular}




\begin{tabular}{|l|l|l|l|l|l|}
\hline Benthic chl $a\left(\mathrm{mg} \mathrm{m}^{-2}\right)$ & & & $\begin{array}{l}11.97 \\
(1.39)\end{array}$ & $\begin{array}{l}57.08 \\
(70.87)\end{array}$ & $54.29(36.87)$ \\
\hline $\begin{array}{l}\text { W/C bacterial counts } \\
\left(\mathrm{x} 10^{11} \mathrm{~m}^{-2}\right)\end{array}$ & & & 52.6 & $36.4(8.6)$ & $33.00(7.4)$ \\
\hline
\end{tabular}


Table 2: Calculated fish and prawn biomass $\left(\mathrm{kg} \mathrm{ha}^{-1}\right)$ in the Murken waterhole.

\begin{tabular}{|l|l|l|l|}
\hline Variable (biomass) & March '04 & June '04 & October'04 \\
\hline Fish (seine net) & 1130 & 210 & 390 \\
\hline Macrobrachium (seine net) & 15.1 & 5.4 & 10.6 \\
\hline Macrobrachium (drag net) & 10.2 & 5.7 & 5.2 \\
\hline
\end{tabular}


Table 3: Mean estimates (SD) of carbon biomass ( $\mathrm{mg} \mathrm{C} \mathrm{m}^{-2}$ ) and flux ( $\mathrm{mg} \mathrm{C} \mathrm{m}^{-2} \mathrm{~d}^{-1}$ ) in Murken waterhole post-flood, and methods or sources of information used. prod $^{\mathrm{n}}=$ production. *assuming coarse benthic particulate organic matter is $1 \mathrm{~cm}$ deep.

\begin{tabular}{|c|c|c|c|c|}
\hline Parameter & March '04 & June '04 & October '04 & Method/Source \\
\hline \multicolumn{5}{|l|}{ Water column } \\
\hline Phytoplankton carbon $\left(\mathrm{mg} \mathrm{C} \mathrm{m}^{-2}\right)$ & $272(23)$ & $253(300)$ & $55(23)$ & C :Chl ratio, Zonneveld (1998) \\
\hline Primary $\operatorname{prod}^{\mathrm{n}}\left(\mathrm{mg} \mathrm{C} \mathrm{m}^{-2} \mathrm{~d}^{-1}\right)$ & $290(186)$ & $40(43)$ & $168(39)$ & ${ }^{14}$ C-bicarbonate incubations \\
\hline Bacterial biomass (mg C m${ }^{-2}$ ) & 247 & $171(40)$ & $155(35)$ & Carbon content and cell counts \\
\hline Bacterial prod $^{\mathrm{n}}\left(\mathrm{mg} \mathrm{C} \mathrm{m}^{-2} \mathrm{~d}^{-1}\right)$ & $590(303)$ & $1043(1151)$ & nd & ${ }^{3} \mathrm{H}$-thymidine incubations \\
\hline \multicolumn{5}{|l|}{ Sediment } \\
\hline Benthic algal carbon $\left(\mathrm{mg} \mathrm{C} \mathrm{m}^{-2}\right.$ ) & $299(35)$ & $1427(1772)$ & $1357(922)$ & C :Chl ratio, Zonneveld (1998) \\
\hline $\begin{array}{l}\text { Based on } 10 \% \text { of total area is in } \\
\text { euphotic zone }\left(\mathrm{mg} \mathrm{C}^{-2}\right)\end{array}$ & 30 & 143 & 136 & \\
\hline Benthic primary prod ${ }^{\mathrm{n}}\left(\mathrm{mg} \mathrm{C} \mathrm{m}^{-2} \mathrm{~d}^{-1}\right)$ & $35(18)$ & $34(10)$ & $143(74)$ & ${ }^{14} \mathrm{C}$-bicarbonate incubations \\
\hline Benthic bacterial $\operatorname{prod}^{\mathrm{n}}\left(\mathrm{mg} \mathrm{C} \mathrm{m}^{-2} \mathrm{~d}^{-1}\right)$ & $244(135)$ & $195(127)$ & $270(75)$ & Oxygen depletion - domes \\
\hline $\begin{array}{l}\text { Coarse benthic particulate organic } \\
\text { matter }\left(\mathrm{mg} \mathrm{C} \mathrm{m}^{-2}\right)^{*}\end{array}$ & 400 & 400 & 400 & Carbon content of benthic detritus \\
\hline \multicolumn{5}{|l|}{ Fish } \\
\hline Fish biomass ( $\mathrm{mg} \mathrm{C} \mathrm{m}^{-2}$ ) & 11879 & 2230 & 3255 & Carbon content measured \\
\hline Fish biomass reduction $\left(\mathrm{mg} \mathrm{C} \mathrm{m}^{-2} \mathrm{~d}^{-1}\right)$ & & 107 & & March -June’04 \\
\hline
\end{tabular}


Table 4 : Contribution of floodplain carbon to total waterhole carbon $\left(\mathrm{mg} \mathrm{C} \mathrm{m}^{-2}\right)$ in Murken waterhole estimated from fish biomass and consumption. Flood period was $38 \mathrm{~d}$. *estimated weight. **\%intake of body weight $\mathrm{d}^{-1}-$ refers to the $\%$ food intake relative to fish body weight (Tacon 1988, Glencross et al. 2006). $\mathrm{Wt}=$ weight, $\mathrm{w} / \mathrm{h}=$ waterhole.

\begin{tabular}{|c|c|c|c|c|c|c|c|c|c|}
\hline \multirow[b]{2}{*}{$\begin{array}{c}\text { Fish } \\
\text { Species }\end{array}$} & \multicolumn{5}{|c|}{ Floodplain } & \multicolumn{4}{|c|}{ Waterhole } \\
\hline & $\begin{array}{c}\text { Age of } \\
\text { fish }\end{array}$ & $\begin{array}{l}\text { Proportion } \\
\text { of cohorts } \\
\text { within each } \\
\text { species } \\
\text { (measured) }\end{array}$ & $\begin{array}{c}\text { Mean Wt } \\
\text { individual } \\
\text { fish in } \\
\text { cohorts (g) } \\
\text { (measured) }\end{array}$ & $\begin{array}{c}\text { \% intake } \\
\text { of body } \\
\text { weight } \\
\mathrm{d}^{-1} * *\end{array}$ & $\begin{array}{c}\text { Biomass } \\
\text { contributing } \\
\text { to w/h (t ha }{ }^{-} \\
1 \text { ) } \\
\text { (calculated) }\end{array}$ & $\begin{array}{c}\text { Mean Wt } \\
\text { individual } \\
\text { fish in } \\
\text { cohorts (g) } \\
\text { (measured) }\end{array}$ & $\begin{array}{l}\text { \% biomass } \\
\text { of each fish } \\
\text { species } \\
\text { (measured) }\end{array}$ & $\begin{array}{c}\text { Biomass } \\
\left(\mathrm{t} \mathrm{ha}^{-1}\right) \\
\text { (measured } \\
\text { ) }\end{array}$ & $\begin{array}{c}\mathrm{C} \text { pool } \\
\text { returned to } \\
\mathrm{w} / \mathrm{h} \\
\left(\mathrm{mg} \mathrm{C} \mathrm{m}^{-2}\right)\end{array}$ \\
\hline \multirow[t]{2}{*}{$\begin{array}{l}\text { Nematolosa } \\
\text { erebi }\end{array}$} & $\begin{array}{c}\text { Larvae/ } \\
\text { juveniles }\end{array}$ & 0.75 & 4 & 10 & \multirow[t]{2}{*}{0.18} & 21 & \multirow[t]{2}{*}{41} & \multirow[t]{2}{*}{0.46} & 1220 \\
\hline & Adults & 0.25 & 54 & 3 & & 54 & & & 1390 \\
\hline \multirow{2}{*}{$\begin{array}{l}\text { Porochilus } \\
\text { argenteus }\end{array}$} & Larvae & 0.73 & $0.1^{*}$ & 10 & \multirow[t]{2}{*}{0.08} & 3 & \multirow[t]{2}{*}{25} & \multirow[t]{2}{*}{0.28} & 280 \\
\hline & Adults & 0.27 & 20 & 3.5 & & 20 & & & 1070 \\
\hline \multirow{2}{*}{$\begin{array}{l}\text { Leiopotherapon } \\
\text { unicolor }\end{array}$} & Juveniles & 0.56 & 1.5 & 10 & \multirow[t]{2}{*}{0.11} & 26 & \multirow[t]{2}{*}{23} & \multirow[t]{2}{*}{0.26} & 170 \\
\hline & Adults & 0.42 & 54 & 2.5 & & 54 & & & 1090 \\
\hline Total & & & & & & & 89 & & 5220 \\
\hline
\end{tabular}




\section{Figure Legend}

Figure 1: Map of the study area. X marks the six sampling sites on the floodplain. Murken waterhole is shown as the thickened region of Cooper Creek in the insert.

Figure 2: (a) Mean (+ SE) areal primary productivity $\left(\mathrm{mg} \mathrm{C} \mathrm{m}^{-2} \mathrm{~d}^{-1}\right)$ in the water column and euphotic zone of the sediment (b) mean ( \pm SD) areal bacterial productivity ( $\mathrm{mg} \mathrm{C} \mathrm{m}^{-2} \mathrm{~d}^{-1}$ ) in the water column (measured using ${ }^{3} \mathrm{H}$-thymidine) and sediment (measured using oxygen fluxes in benthic chambers) at three sites on three sampling occasions in Murken waterhole. nd = no data.

Figure 3: Comparison of the mean (SE bars) ${ }^{13} \delta \mathrm{C}$ signatures (\%o) for a range of trophic levels on the floodplain during the January 2005 floods with Murken waterhole between March and October 2004. Closed triangle - benthic algae, closed diamond - Macrobrachium, open squares - three dominant fish species, closed square - macroinvertebrate (Notonectid), open diamond - CPOM (coarse particulate organic matter), cross - zooplankton.

Figure 4: Conceptual diagram of the relative changes in biomass of fish, algae and bacteria during pre-flood (Bunn et al. 2003; Balcombe et al. 2005; Fellows et al. 2007), flood and post-flood conditions. Size of text is proportional to magnitude of carbon pool. 